\title{
Strome van lewende water: Nuwe-Testamentiese perspektiewe op die missionêre karakter van die kerk
}

\author{
Author: \\ P.J. (Flip) Buys \\ Affiliation: \\ ${ }^{1}$ Department of Missiology, \\ North-West University, \\ Potchefstroom Campus, \\ South Africa \\ Correspondence to: \\ Flip Buys \\ Email: \\ 11004835@nwu.ac.za \\ Postal address: \\ PO Box 1042, Rayton 1001, \\ South Africa \\ Dates: \\ Received: 01 Nov. 2011 \\ Accepted: 12 Apr. 2012 \\ Published: 03 May 2013 \\ How to cite this article: \\ Buys, P.J., 2013, 'Strome \\ van lewende water: Nuwe- \\ Testamentiese perspektiewe \\ op die missionêre karakter \\ van die kerk', In die Skriflig/ \\ In Luce Verbi 47(1), Art. \#97, \\ 11 pages. http://dx.doi. \\ org/10.4102/ids.v47i1.97

\section{Copyright:} \\ C 2013. The Authors. \\ Licensee: AOSIS \\ OpenJournals. This work \\ is licensed under the \\ Creative Commons \\ Attribution License.
}

Read online:
Oor ' $\mathrm{n}$ wye front word besorgdheid uitgespreek oor die stagnering en kwynende getallegroei van hoofstroom-reformatoriese kerke in Suid-Afrika. Die besorgdheid word egter ook uitgespreek dat predikante en kerke in hulle ywer om kerklike vernuwing teweeg te bring, soveel kompromieë maak dat die kerk sy eie aard as heilge volk van God in die wêreld verloor. Daar is 'n internasionale tendens te bespeur by reformatoriese kerke, in Suid-Afrika, Noord Amerika, Australië, Nederland, Duitsland en die Verenige Koninkryk om die na-binne-gerigtheid van kerke om te draai om werklik missionêre kerke te kan wees. Daar is ook tekens van 'n groeiende ontwakende passie om die onbereikte taalgroepe tot by die uithoeke van die aarde te bereik met die evangelie. Daar is oor ' $n$ wye front lewendige debatte aan die gang wat vra vir 'n herevaluering van oorgeërfde ekklesiologiese tradisies en gebruike en 'n herbesinning oor Bybelse beginsels. In die lig van hierdie ontwikkelings is die doel van hierdie artikel om Nuwe-Testamentiese beginsels op te som en te onderstreep en as boustene aan te bied om die profiel van 'n missionêre kerk te skets.

Streams of living water: New Testament perspectives on the missional character of the church. Grave concerns are expressed about the decline of mainline reformed churches in South Africa, especially the Reformed Churches in South Africa. At the same time fears are expressed that efforts to facilitate renewal in churches in order to become healthy and more effective missional churches, are making too many compromises with the gospel, so that the church is in danger of losing its very character as God's holy people in the world. There is also an international phenomenon of reformed and evangelical type churches in North America, the Netherlands, Germany, the UK and Australia endeavouring to outgrow their ingrown vision and become part of God's mission to reach unreached people groups in every corner of the world. There are lively debates on reviewing and rethinking inherited ecclesiological theological traditions and practices in churches. This article endeavours to gather basic building bricks by summarising and emphasising the most basic New Testament principles for outlining the profile of a missional church.

Sover ek kon vasstel (ook deur die insette van taalkundiges) is die terme missionêre en missionaal in Afrikaans sinoniem. Missionêr kom van die Nederlandse woord 'missionair' en missionaal is afkomstig van die Engelse 'missional'. Sonder taalkundige of werklik bewese teologiese gronde word soms aanvaar dat missionêre dui op dit wat ' $n$ kerk doen, terwyl missionaal aandui wie 'n kerk is. Ek verkies die term missionêr bloot omdat dit ' $n$ meer bekende term is in die nie-Angelsaksiese reformatoriese tradisie. Ek verstaan daaronder die gestuurde of sendingaard van die kerk (Joh 20:21) en dit sluit in wat die kerk is en doen. Die kerk is die volk van God wat deur Jesus Christus in die wêreld ingestuur word as sy instrument om deel van sy sending te wees. Sodoende word die doel van Christus se eie sending deur die Vader vervul, naamlik dat die eer en heerlikheid van God in die herstel van sy hele skepping bekendgestel moet word (Van Swigchem 1955; Van Engen 1991; Wright 2006; 2010; Glenn 2007) en dit bepaal juis sy totale doen en late. Guder (ed.) (1998:1-17) en Keifert (2006:21-38) redeneer dat daar ingrypende teologiese verskille is in die gebruik van die terms 'missionary' en 'missional'. De Young en Gilbert (2011:26) het. na 'n indringende bestudering van 'n groot aantal kontemporêre outeurs se publikasies oor die roeping van die kerk in die wêreld, myns insiens (m.i.) tereg aangetoon dat die kritiek van Stephen Neill (vgl. De Young \& Gilbert 2011:15) steeds geldig is. Bosch (1991:511) haal dit aan: 'If everything is mission, nothing is mission.' In sy proefskrif oor Leslie Newbigin toon Goheen (2000:23 e.v.) aan dat Newbigin na sy paradigmaskuif bloot gepraat het van 'From a Christendom Ecclesiology to a Missionary Ecclesiology'. Die gebruik van die term missionaal in Afrikaans hou ook nie rekening daarmee dat die term 'missionair' en 'missionarische' steeds algemeen in Nederland (vgl. Paas 2006:6-26) en Duitsland gebruik word om 'missional church' te vertaal nie. Die term missionaal word dus nie in Europa gebruik om 'n paradigmatiese verskil in die wese van sending aan te dui nie. Ek het geen paradigmatiese probleem om in Engels die term 'missional' te gebruik nie, maar is in navolging van kontemporêre Nederlandse en Duitse sendingwetenskaplikes nie oortuig daarvan dat die term missionaal 'n noodwendige noodsaaklikheid in Afrikaans is nie.

\section{Inleiding: Die relevansie van hierdie studie}

\section{Sorge oor kwynende getalle en die gebrekkige missionêre krag in Gereformeerde Kerke in Suid-Afrika}

In Gereformeerde Kerke van Suid-Afrika (GKSA) word oor 'n wye front kommer uitgespreek oor die kwynende getalle en gebrek aan sendingywer in die GKSA (Botha 2005:9; 
De Klerk 2007:10; Kruger 2006:15; Smit 2009:4; Van Loggerenberg 2007:15).

Een van die gerespekteerde emerituspredikante bring hierdie sorge in Die Kerkblad soos volg onder woorde:

Het ons in die amp van die geloof ons fut verloor om gereformeerd te wees en om na buite te beweeg? Met ander woorde, laat ons ons lig skyn of sit ons in selftevredenheid terug? Waarom daal ons getalle so erg en is daar groei by andere? Moenie emigrasie en demografie as argument gebruik nie - daar is genoeg soekendes! (Kruger 2006:15).

Verstedeliking het ook gelei tot krimping van getalle op die platteland (in sommige gevalle het lidmaatgetalle gedaal van 650 in 1958 tot 143 in 2008; vgl. Snyman 2008:13). Verskeie oproepe word gemaak om nuut en kreatief oor kerkwees en die totstandkoming van nuwe kerke te dink of die verstewiging van bestaande kerke deur nuwe vennootskappe (kombinasies) te vorm om die basis vir nuwe verbeeldingryke uitreike te vorm (Venter 2011:5; De Klerk 2007:10).

Daar word egter ook gewaarsku dat sommige gemeentes en predikante so desperaat raak om nuwe lidmate te wen en die dalende syfers van lidmaatgetalle om te draai, dat hulle nie meer goeie onderskeidingsvermoë aan die dag lê in hulle strategieë om verandering teweeg te bring nie.

Hierdie besorgdheid is soos volg deur die voorsitter van die Algemene Sinode van die Gereformeerde Kerke in SuidAfrika onder woorde gebring (Smit 2009):

Ons moenie senuweeagtig rondspring in die najaging van 'n lewendige kerk nie. Ons moet ons beywer vir 'n lewende kerk waarin die hartslag van die gereformeerde belydenis opklink en in ons lewenswandel blyk. (bl. 7)

Die vrees word ook uitgespreek dat kerke soveel kompromieë met hulle erediensstyl en bediening maak, dat die kerk sy unieke karakter as volk van God in die wêreld verloor (Venter 2011:5).

Tydens die Algemene Sinode van Januarie 2012 is 'n besluit met algemene stemming aanvaar dat die GKSA 'n omkeerstrategie moet implementeer om die stagnasie en na-binne-gerigtheid van die kerke om te keer sodat hulle daardeur lewende, groeiende kerke kan word (GKSA 2012:767). ${ }^{1}$

\section{Wêreldwye nuwe besef van die dringendheid van die getuienisroeping van elke Christen en ook die hele gemeente as Liggaam van Christus}

In Christelike kerke wêreldwyd is 'n nuwe belangstelling in die getuienisroeping van die kerk in sy totaliteit en die geweldige onvoltooide sendingtaak wat nog vervul moet word.

1.Die publikasie van Gaum (2012) is ook verteenwoordigend van baie publikasies oor hoe die Nederduitse Gereformeerde Kerk in Suid-Afrika ook met die probleem van krimpende getalle worstel en vrese het dat die kerk vir baie Suid-Afrikaners irrelevant geraak het.

\section{Historiese ontwikkeling}

Oor 'n periode van 1000 jaar het die kerke in die Europese en Angel - Saksiese wêreld te doen gehad met 'n samelewing waarin die Christendom 'n oorheersende invloed gehad het. Die meerderheid van die mense in die samelewing was in naam Christene. Daar was dus 'n Christelike kultuur met breë en dikwels vae Christelike waardes wat die samelewing beïnvloed het, alhoewel baie mense nie werklik wedergebore was nie en nie in 'n lewende, persoonlike verhouding met God deur Jesus Christus gelewe het nie (Carter 2006:22; Keller 2001:2; Hirsch 2006:57-66).

Die kerk het dit as sy taak gesien om lidmate van die kerk met die kern van die evangelie te konfronteer om in 'n lewende en deurleefde verhouding met Christus te tree. Hierdie Christendom het voordele en nadele vir die uitbreiding van die koningskap van Christus ingehou. Dit was voordelig dat daar 'n taamlik algemene Christelike verstandhouding in die Westerse samelewing geheers het oor etiese waardes ten opsigte van wat goed of sleg is (Keller 2001:2). Die nadeel was egter dat daar sekere waardes gehandhaaf is sonder dat mense se harte werklik diepgaande deur die evangelie van Jesus Christus in die diepste kern van hulle menswees geraak is. Godsdiens was dikwels 'n blote rasionele oefening en instandhouding van oorgeërfde tradisies. Die regte leerstukke is rasioneel aanvaar, maar dikwels nie uitgeleef nie. Die na-binne-gerigtheid van gemeentelike bediening het tot geloofsvervlakking en 'n verbruikersmentaliteit by Christene gelei. Dit is goed verwoord in die konfronterende titel van Jack Miller (1986) se boek, Outgrowing the ingrown church.

In die woorde van Ogden (1990:10-30) is die predikant gesien as die 'dominant pastoral superstar mister omnicompetent, know it all, do it all' en gelowiges is gesien as 'spectators, critics, and recipients of pastoral care, free to go about their own business because the pastor is taking care of the business of the kingdom'.

Hierdie soort godsdiens het dikwels ook as skynheilig, brutaal en liefdeloos oorgekom. In konserwatiewe dorpies is 'n ongetroude ma dikwels uitgestoot en die Christedom het dikwels oor magsmisbruik en blantante onreg in die samelewing geswyg (Keller 2001:1). Dit het veroorsaak dat die hoofstroomkerke in Europa en Noord-Amerika en in die blanke geledere in Suid-Afrika sedert die middel van die negentiende en veral sedert die middel van die twintigste eeu, sy bevoorregte posisie verloor het. Globalisering, toenemende multikuturaliteit en die groeiende armoede roep ook na nuwe modelle van holistiese sending waar die gemeente as die Liggaam van Christus na die wêreld uitreik (Escobar 2003:68).

Die Britse sendeling Lesslie Newbigin het in 1936 na Indië gegaan en daar ervaar dat ' $n$ kerk baie meer radikaal sy lewende verhouding met Jesus Christus moet uitleef indien die oorheersende kultuur in die samelewing nieChristelik van aard is. Met sy teruggekeer na Engeland het 
hy steeds meer onder die indruk gekom dat die kerk in die Westerse wêreld as gevolg van sekularisme ${ }^{2}$ ook in 'n nieChristelike wêreld leef, maar nie regtig in sy ekklesiologie en bedieningstyl daarby aangepas het nie (Goheen 2000:12-23; Newbigin 1989:55). ${ }^{3}$

Alhoewel openbare instansies en die populêre kultuur nie meer oorheersend deur Christene beman is nie, het die kerk steeds ' $n$ bedieningstyl bly handhaaf wat veronderstel dat 'n stroom Christelike mense kerk toe sal kom. Sommige kerke het nog evangelisasiebediening as 'n onderdeel van hulle aktiwiteite behou. Die meeste hoofstroomkerke het egter sy werklike impak op die nie-Christelike samelewing verloor en getalle van getroue kerkgangers kwyn. 'n Missionêre gerigtheid op die ongelowige samelewing in elke aspek van kerkwees het in die meeste hoofstroomkerke, nie 'n werklikheid geword nie.

In Wes-Duitsland het die Evangelische Kirche dieselfde probleem ervaar. Karl Rennstich was jare lank sendeling in Indië en met sy terugkeer na Duitsland het hy ontdek dat Wes-Duitsland net so ongekerstend en buitekerklik geraak het as Indië. Predikante was nie toegerus om gemeentes te lei om missionêre gemeentes te wees nie. Hy is versoek om met 'n heropleiding van predikante te begin om hulle toe te rus hoe om gemeentes weer missionêre gemeentes te laat word. ${ }^{4}$ Gevolglik het daar sedert 1992 'n Pastoralkoleg Urach in Bad Urach naby Tübingen onder leiding van Karl Rennstich vir die heropleiding van predikante ontstaan. Daar is ' $\mathrm{n}$ sterk oortuiging dat gemeentes nie missionêr ingestel is nie, en nie na byna $90 \%$ van die Duitse bevolking wat buite-kerklik is, uitreik nie, omdat voorgangers ook nie toegerus is om die gemeentes te lei om missionêre gemeentes te wees nie.

Die Gereformeerde Kerke in Australië (Christian Reformed Churches of Australia [CRCA] 2006) het in 2006 as die resultaat van diepgaande missionêre strategiese beplanning besluit om biddend, doelgerigte groeiprosesse aan die gang te sit. Daar is besluit om gemeentes toe te rus, op te lei en te stimuleer om soveel as moontlik nuwe gemeenskappe (bedieningspunte) en gemeentes te laat ontstaan om gelowiges sodoende toe te rus om samelewingstrukture met die evangelie te deursuur en hulle naaste vir Christus te wen.

\section{Onvoltooide sendingtaak}

Sedert die Lausanne-beweging in 1973 tot stand gekom het, het daar in evangeliese kerke 'n groeiende nuwe bewustheid van die onvoltooide sendingtaak gekom. Allerlei navorsingsinstansies het ontstaan wat taal- en bevolkingsgroepe wat nog nooit met die evangelie bereik is

2.Clowney (1958) het ook reeds in 1958 die invloed van sekularisme op kerke in die Weste op die volgende manier verwoord: ' ... while the missionaries of the Christian West have gone to the ends of the earth, the homelands of the mission have been progressively de-Christianized'.

3.Newbigin het ook teenoor Goheen (2000:11) getuig dat hy baie sterk deur die boek van Roland Allen (1983) beïnvloed is.

4.Oor die oogmerke van hierdie opleiding is Rennstich (1993:3) eksplisiet: 'Ziel der Arbeit des Pastoralkoleg's Urach soll es sein, realistische Modelle für Gemeindeaufbau/ Gemeindeerneuerung zu arbeiten und zukunftsorientierte Gemeindeformen zu finden, die es Theologen und Laien gemeinsam ermöglichen, bewuszt als Christen in der säkularen, multikulturellen und multireligösen Gesellschaft zu leben. nie, onder die aandag gebring het. Die US Centre for World Missions, die AD-2000-projek en die Joshua Project het reuse werk in hierdie verband gedoen. Hulle doen dit, tewens, nog steeds om Christelike kerke op te roep om saam te werk om die beraamde 6600 etniese groepe waar daar nog minder as $2 \%$ Christene is, met die evangelie van Jesus Christus te bereik. $^{5}$

\section{Groei en verval}

Verskeie navorsers wys daarop dat die fokuspunt van die Christendom reeds van die noordelike na die suidelike halfrond verskuif het (vgl. die trilogie van Jenkins 2002, 2006, 2009). In die Februarie 2000-uitgawe van die tydskrif Time Europe (Monrovia 2000), het 'n artikel verskyn wat aantoon dat die Christendom in Afrika, Suid van die Sahara op die oomblik vinniger as op enige ander plek in die wêreld in getalle groei. Die berekening is dat daar wêreldwyd tans 4000 nuwe gemeentes per week tot stand kom en dat dit in die volgende drie jaar na 12000 per week sal groei. (Landrey 2009).

Vir die Afrikakontinent is die skatting dat daar weekliks 300 nuwe gemeentes tot stand kom (Buys 1999). Die Evangelies Christelike Kerk in Zambië het byvoorbeeld 675 gemeentes, maar slegs 30 opgeleide predikante. ' $n$ Ander kerk in Uganda het 1000 gemeentes, maar slegs agt opgeleide predikante.

\section{Emergent Church-beweging}

Die Emergent Church-beweging, met leidende figure soos McLaren (2001) en Jones (2003), propageer 'n eie benadering wat kerke, volgens hulle, moet gebruik om 'n missionêre impak op die postmoderne wêreld te maak. Dit kom daarop neer dat die klem minder op leer en dogma moet val, dat daar 'n postmoderne openheid moet wees om 'n diversiteit van denkrigtings te akkommodeer, meer outentieke spirituele ervarings gesoek moet word deur gebruik te maak van nuwe spirituele oefeninge en 'n ywer vir sosiale geregtigheid in die samelewing aan die dag te lê. ${ }^{6}$

\section{'n Sendingontwaking by kerke in Suid-Afrika?}

Uit 'n rapport van die sinodale sendingdeputate van die Gereformeerde Kerke in Suid-Afrika wat in 1985 voor die sinode gedien het (GKSA 1985:148-153), is 'n verontrustende tendens onderstreep:

5.Kyk gerus by http://www.uscwm.org/uploads/pdf/psp/winter_koch_finishingthetask. pdf na die inligting oor die onvoltooide sendingtaak.

6.Om die Emergent Church krities te evalueer is 'n studie op sigself. Ek verwys slegs daarna as nog 'n aanduiding dat nuwe besinning oor Nuwe-Testamentiese perspektiewe ook vir die aanhangers van hierdie beweging relevant is. Sleutelpublikasies wat kan dien om hierdie beweging te verstaan en te evalueer, is McLaren (2000 \& 2003 en Jones (2005). Gebalanseerde kritiese evaluerings kan gevind word by Driscoll (2007, aanvanklik deel van die Emergent Church-beweging, maar later ontnugter deur die totale relativisme daarvan) en Carson (2005) Woodbridge (2008) gee'n gebalanseerde evaluering van die erediensstyl in hierdie beweging. Hirsch (2006:17) is van mening dat 'much of the thinking of the so-called emerging church leaves the prevailing assumptions of church and mission intact and simply focusses on the issue of theology and spirituality in a postmodern setting'. Vir ' $n$ indruk oor hoe die Emergent Church in Suid-Afrika tot ontluiking kom, is die verhandeling van Breedt (2009) ' $n$ goeie voorbeeld. Die kritiek van Van Rensburg (2011) het ook tot heelwat diskussies gelei oor die Emerging Church se invloed in (2011) het ook tot heelwat diskussies gelei oor die Emerging Church se invloed in Suid-Afrika. Wat egter in die besprekings gemis word, is die vraag of die Emergen Church-beweging hoegenaamd relevant is vir Afrika. Daar is ontsaglike groei van Christelike kerke in Afrika sonder dat hulle besorgd is oor postmodernisme of die Emergent Church-beweging. Die proefskrif van Atoyebi (2010) toon juis aan dat stagnerende kerke in Afrika op verbeeldingryke maniere omdraai en gesonde groeiende kerke word wat ' $n$ impak op die samelewing het, wanneer die evangelie in sy rykdom en diepte onverskrokke verkondig word. 
- Nagenoeg $40 \%$ van die kerke doen nie aktief sendingwerk nie.

- Nagenoeg 33\% van die lidmate stel nie in sending belang nie.

- Nagenoeg 50\% van die kerke dra slegs deur ramings tot sending by.

- Meer as $75 \%$ van die kerke bestee minder as $10 \%$ van hulle inkomste direk aan sending.

- Daar is baie min kennis van dit wat in ander bevolkingsgroepe se lewens aangaan.

- In die sendingwerk van byna $60 \%$ van die kerke was daar gedurende vyf jaar minder as 10\% groei.

- Meer as 70\% van die kerke dink dat hulle minder as $10 \%$ van die swart bevolking met hulle werk bereik.

Die afleiding kan uit hierdie rapport gemaak word dat daar by baie gereformeerde Christene 'n gebrek aan bybelse godsvrug is en daarom openbaar hulle min offervaardigheid en ywer om deel van God se sending (die missio Dei) in die wêreld te wees.

Sending en evangelisering is deur die meeste gereformeerde Christene en kerke in Suid-Afrika dikwels as 'n soort stokperdjie vir bepaalde geesdriftiges beskou. Baie min het dit as 'n heilige roeping en onmisbaar-integrale deel van Christenskap en kerkwees beleef en uitgeleef.

Daar is heelwat aanduidings dat hierdie tendens gelukkig besig is om te verander. ' $n$ Nuwe ywer is by kerke in SuidAfrika aan die ontwikkel om met sendingwerk in ander Afrikalande en ook in ander kontinente betrokke te raak. Korttermynsendinguitreike en die uitstuur van voltydse sendelinge na ander lande wêreldwyd het die afgelope twee dekades nuwe stukrag in gereformeerde kerke in Suid-Afrika sowel as in ander kerkverbande gekry. Daar is ook heelwat berigte van kerke wat in hulle eie omgewing met aksies begin om nuwe multikulturele gemeentes te vestig.

In die lig van hierdie stroomversnellings moet opnuut gekyk word na Nuwe-Testamentiese en reformatories-teologiese beginsels oor die roeping van die kerk in die wêreld. Die publikasies van Goheen (2011), Wright (2010), De Young en Gilbert (2011), Stetzer (2006) en Hirsch (2006) is voorbeelde van hoe daar opnuut vanuit die Skrif gesoek word na perspektiewe oor die wyse waarop die kerk sy roeping moet vervul.

Hierdie artikel wil vanuit 'n reformatoriese perspektief ${ }^{7}$ bybelse beginsels aanstip wat perspektief kan bied op die soeke na verdieping en 'n inspirerende visie vir skrifgetroue roepingsvervulling.

7.In die lig daarvan dat In die Skriflig/In Luce Verbi reformatoriese teologie wil uitbou, gaan hierdie artikel uit van'n reformatories-hermeneutiese interpretasie wat die Nuw The wat die Nuwe The met Jordaan, Van Rensburg en Breed (2011:225-258) se uiteensetting van die Gereformeerde Hermeneutiek. Dit val egter buite die skopus van hierdie artikel om te beredeneer dat hierdie hermeneutiese vertrekpunte geensins met 'n missio Deiperspektief in 'n sendingparadigma bots nie.
Nuwe-Testamentiese perspektiewe

Sending word ten diepste gemotiveer deur'n groeiende, ontsagwekkende verbasing oor wie God werklik is en waarheen Hy op pad is

Wanneer Paulus in 2 Korintiërs 5:11 sy sendingywer motiveer, verklaar hy onomwonde dat sy ontsag vir die Here

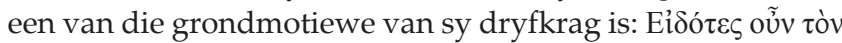

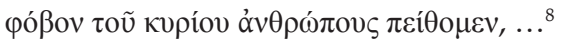

Die woord vrees is 'n mengsel van vurige liefde en heilige ontsag en is volgens Handelinge 9:31 tiperend van die spiritualiteit van die eerste Christelike gemeente. Terwyl hulle geleef het met diep ontsag vir die Here (gewandel het in die vrees van die Here) en die vertroosting van die Heilige

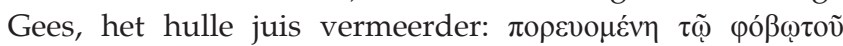

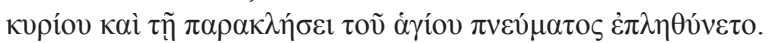

John Piper (1993:7) maak dit duidelik dat missiologie volgens die Nuwe Testament in doksologie gewortel is. Sending is nie die einddoel van die kerk nie, maar wel ware deurleefde aanbidding van die Here in al sy heerlikheid en majesteit deur 'n verloste gemeenskap van mense uit elke stam en taal en volk en nasie (Op 5:9; 7:9). R.W. Glenn (2007) formuleer sy definise van sending soos volg:

Through Jesus Christ, and by the Holy Spirit, God, for his own glory, will unite people from every tribe, nation, kingdom, and language to worship him forever in the New World.

Omdat daar nou nog so baie mense aarde is wat nie bekend is met ware aanbidding van die lewende God nie, is daar juis nog 'n groot sendingtaak wat wag. Wanneer die koninkryk finaal in al sy heerlikheid gekom het, het die sendingtaak van die kerk sy eindpunt bereik. Sending is die semifinale doel van die kerk - aanbidding is die finale doel.

Egte geesvervulde erediens is daarom 'n missionêre lanseerblad. Die Heilige Gees se doel is om die hele aarde onder die heerskappy van Christus te bring. Hy wil daarmee die heerlikheid van Jesus Christus sigbaar laat word in die kerk, en die gelowiges wat Hy aan Jesus Christus verbind het, getuies van Christus maak om ander mense in die stukkende wêreld waarin ons leef, te oortuig dat Jesus Christus alleen die Redder, Here en Koning is.

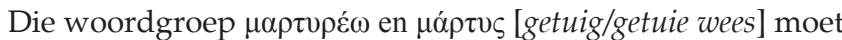
vanuit die Ou-Testamentiese gebruik verstaan word (vgl. ook Goheen 2011:126 e.v.; Wright 2010:163-178). Hieruit word dit duidelik dat dit daarom gaan om die Here God as die enigste ware God van die heelal te ken en te erken en oor Hom as die enigste Verlosser en Here te getuig. Jesaja 44:8 is 'n goeie voorbeeld:

Moenie skrik nie, moenie bang wees nie! Het Ek dit nie van lankal af aan julle verkondig, dit vir julle gesê nie? Julle is my getuies: Is daar'n God buiten My? Daar is geen ander Rots nie; Ek weet van geeneen nie.

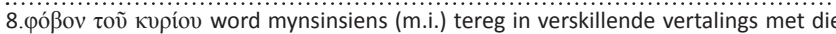

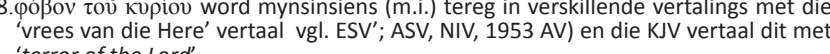
'terror of the Lord'. 
Die implikasie daarvan is dat 'n getuie eerstens moet weet wie God regtig is en dan in die regte verhouding van liefdevolle oorgawe en kinderlik ontsag vir Hom moet leef. Hy moet al die nasies van die wêreld gaan bly maak deur juis aan hulle te getuig wie God werklik is, sodat hulle hom sal ken, bely en vrees as die enigste ware God.

Psalm 67:4-5 verwoord dit so: 'Mag die volke U loof, o God, mag al die volke U loof! Mag die nasies bly wees en jubel.'

Psalm 67:7 stel dit onomwonde dat die Here wil hê dat die nasies van die wêreld Hom sal vrees. ${ }^{9}$

Ten diepste is die doel van ons getuienistaak in die wêreld om gedring en bemagtig deur die Gees, deel te word van God se strome van lewende water (Joh 7:37-39) en om God groot te maak deur die nasies van die wêreld bly te maak. Dan is ons deel van die missio Dei.

Niks kan dieper vreugde gee as om die enigste ware God te ken en te vrees nie. Dit is God se groot doel met sy hele raadplan. Hy wil sy eer en sy heerlikheid in hierdie stukkende, korrupte en gebroke wêreld waarin ons leef, herstel. So wil Hy ewige vreugde gee aan elkeen wat deur die Heilige Gees getrek word om God self deur Jesus Christus as die enigste ware God te leer ken en uit liefde en ontsag te gehoorsaam.

\section{Die eer van God is primêr, oorkoepelend en bepalend}

Kwalitatiewe sowel as kwantitatiewe opbou en groei van die kerk het ' $n$ teosentriese doksologiese doel. Die einddoel van alles is immers dat God weer alles en in almal sal wees ( 1 Kor 15:28). Die oorkoepelende doel van alle opbou en groei, is die

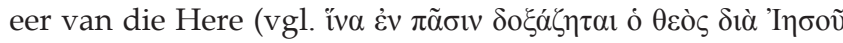

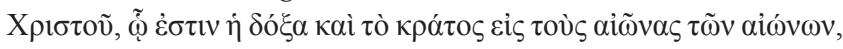
$\dot{\alpha} \mu \eta \dot{v} v$ wat die hele doel van die opbou van die gemeente in 1 Pet 4:11 beskryf).

Sy eer word egter juis daarin sigbaar dat sy kerk enersyds in heiligheid groei (vgl. Ef 5:27; Op 15:4 en 1 Pet 3:18 waar die groei in genade en kennis direk verbind word aan die heerlikheid van die Here) en andersyds na volkomenheid in getallegroei (vgl. bv. hoe Paulus in Ef 1:11-14 die gemeente

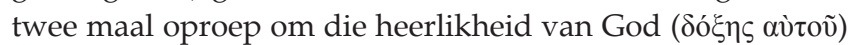
te prys juis omdat hulle die eerstes geword het in die proses waarin God sy volk vergader).

Volgens Matteus 28:18-20 vloei die opdrag om dissipels van al die nasies te maak voort uit die soewereine alomvattende heerskappy van die opgestane Here. Mense word onder die soewereine heerskappy van Jesus Christus gebring deur hulle in sy Naam te doop (wat in die betrokke teks veral die betekenisnuanse het van inlywing in die gemeente van Christus) en hulle ook te leer om alles te onderhou wat Hy beveel het. Derhalwe is sowel die kwalitatiewe as die kwantitatiewe opbou van die gemeente'n erkenning van die soewereine koningskap van 'n mengsel van vurige liefde en heilige ontsag, verstaan word. van Christus. De Ridder (1971:88) maak dit duidelik dat indien Matteus 28:16-20 vergelyk word met die struktuur van die verbond in die Ou Testament, word dit duidelik hoe die opdrag om dissipels van al die nasies te maak, deel is van die proklamasie van die Koning as soewereine Maghebber van die heelal wat verbondsgehoorsaamheid eis (vgl. ook Buys 1984:38-43).

Die kerk is daarom nie primêr kerk vir die wêreld nie, maar kerk vir die Here! Hy roep die kerk om deel te wees van sy sending. Daarom is dit missio Dei-God se sending, wat juis voortvloei uit Jesus se proklamasie dat Hy alle gesag $(\pi \tilde{\alpha} \sigma \alpha$ $\grave{\varepsilon} \xi o v \sigma i ́ \alpha)$ ontvang het. As gelowiges egter werklik diep in hulle harte gegryp is deur so ' $n$ teosentriese gerigtheid, sal dit die kerk enersyds van horisontalistiese verwêreldliking in sy bediening en uitreik na buite bewaar, maar andersyds ons ook bewaar van 'n sieklike selfgesentreerde en selfsugtige na-binne-gerigtheid (Miller 1986:33).

\section{Integrale eenheid en verweefdheid tussen bewaring en vermeerdering van die kerk}

In praktiese kerkwees en in alle fasette en gestaltes van gemeenteopbou soos prediking, onderrrig, pastoraat, aanbidding in die gesamentlike erediens, bestuur en leiding van die voorgangers en onderlinge meelewing (koinonia) in die kerk, moet die eg Nuwe-Testamentiese verweefdheid en integrale eenheid tussen die bewaring en die vermeerdering van die kerk voortdurend in die oog gehou word. Daar moet met nuwe helderheid besef word: om te kan bewaar, moet die kerk blywend met ' $n$ heilige passie op vermeerdering gerig wees. Om egter te kan vermeerder, moet die gelowiges in ' $n$ hegte liefdesverhouding tot God en tot mekaar bewaar word.

Daarom word vervolgens gekyk na kardinale faktore in verskillende aspekte van 'n missionêre gemeente se bestaan.

\section{Visie by die predikant en kerkraad vir'n gemeente wat gebalanseerd groei}

Visie beteken om God se unieke roeping vir 'n spesifieke gemeente duidelik te verstaan en by al die gemeentelede tuis te bring. Onder visie verstaan ek die insig en leiding van die Heilige Gees wat voorgangers ontvang van God se besondere roeping vir die spesifieke gemeente in 'n spesifieke tydsgewrig waarin Hy die spesifieke gemeente geroep het om as sy volk te leef en te werk. Vir'n gelowige voorgangeriemand wat God geroep het om leiding te gee in die gemeente van Christus - is 'n skrifgefundeerde missionêre visie nie 'n opsie nie. Dit is 'n absolute noodsaaklikheid.

Die woorde leiding gee (1953 vertl. voorganger en in Grieks

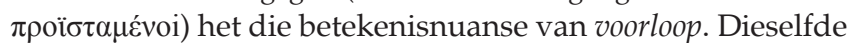
woord word in 1 Tessolonisense 5:12 ook met voorgaan of lei vertaal. In 1 Timotius 3:4-5, 12 en 5:17 word dit met regeer vertaal en vir die ouderlinge sowel as die diakens gebruik.

Die beeld wat in hierdie woord lê, is dié van iemand wat vooruitgaan, voor loop of voor staan. Dit hou in dat 'n ware 
visionêre leier iemand is wat 'n paar treë vooruitloop en dink in terme van die toekoms. Hy is soos die herder in Israel wat nie agter die skape nie, maar voor hulle loop sodat hulle hom volg.

Empiriese navorsing het tot die interessante konklusie gelei dat plaaslike kerke wat werklik groei (in geestelike verdieping en dikwels ook in getalle) gewoonlik gelei word deur voorgangers met sterk leierskapsgawes. Hullle dwing die respek en vertroue van die gelowiges af - nie op grond van institusioneel toegekende gesag nie, maar op grond van innerlike integriteit en oorredingsvermoë. Hulle kan die gelowiges inspireer om werklik te deel in 'n verbeeldingryke toekomsvisie vir die kerk.

Atoyebi (2010) toon in sy proefskrif 'n interessante feit aan by die kerke in Nairobi wat hy ondersoek het. Hy het naamlik ondersoek ingestel na die aard en redes vir hulle merkwaardige omdraai vanaf stagnerende kerke na lewende, groeiende kerke. By elkeen van die kerke het die omdraai van die kerk gepaard gegaan met die vervanging van voorgangers met leiers wat visie en 'n diensknegleierskapstyl openbaar.

Om God se gemeente te lei sonder om behoorlik te weet wat sy wil vir sy gemeente is, is ' $n$ gevaarlike spel. Sodanige optrede sal God nie behaag nie en op die lang duur die gelowiges ook frustreer. Sonder ' $n$ duidelike visie sal gelowiges nie verstaan waarom dinge gedoen word soos wat dit in die gemeente gedoen word nie en waarheen die gemeente op pad is nie. 'n Gemeente sonder 'n duidelike visie of 'n gemeente wat willekeurig besluite neem wat nie uit 'n duidelike visie voortvloei nie, is 'n gemeente sonder dryfkrag en ywer. Sonder visie maak die algehele onsekerheid mense koersloos, beangs en neerslagtig. Die enigste manier om mense van ondergang in pessimisme en defaitisme te bevry, is om hulle te help om werklik 'n geloofsvisie op God se roeping vir sy gemeente te kry.

Visie is iets wat gevisualiseer, dit wil sê, duidelik in 'n mens se geestesoog gelowig gesien kan word. Daarom moet dit duidelik en in konkrete terme uitgespel kan word. Vae filosofiese formulerings is nie werklik ' $n$ visie wat mense laat oorgaan tot aktiwiteit nie. Wat Dayton en Engstrom (1989) oor die algemeen van voorgangers in Christelike kerke sê, geld dalk in besonder van gereformeerdes:

Christian organizations have a great tendency to define their purposes, and never get around to stating clearly what they intend to do. They suffer from 'fuzzability thinking'. They state things in such broad terms that it is often difficult to tell whether they have accomplished what they set out to do. (bl. 52)

M. te Velde (wat die vak Gemeenteopbou by die Teologiese Skool van die Gereformeerde Kerken [vrijgemaakt] in Kampen doseer) sê dat predikante soms bietjie afstand moet neem van hulle werk en hulleself die volgende afvra:

Waarmee is ek besig? Wat wil ek eintlik bereik? Het ek my neergelê by bestaande toestande en my klakkeloos aangesluit by die gangbare werkmetodes of het ek regtig 'n visie? Waaraan moet ek die meeste van my energie bestee? (Te Velde 1992:82)
Wat veral belangrik is, is wat hy daarna van die gemeente sê:

Dat geld trouwens niet alleen voor een predikant. Een duidelijke visie op wat de gemeente is en worden moet, is nodig voor ieder die in de gemeente werkt. Dat is voor de gemeente als geheel nodig. Een gemeente kan heel gauw vasgeroest raken in een bepaald patroon. We doen de dingen zoals we ze altijd al deden en daarmee zijn we dan tevreden. Dan wordt een gemeente slaperig, tevreden met zichzelf of onverschillig en laconiek. Dan boet de gemeente in aan kracht en dynamiek. Dan zit er geen ontwikkeling meer in. En stilstand is achteruitgang. Dat is 'de dood in de pot'. (Te Velde 1992:82)

Die Gereformeerde Kerke in Australië (Christian Reformed Churches of Australia (CRCA) 2006) het in 2006 selfs op sinodale vlak besluit om vir die hele kerkverband 'n visie te formuleer met die woorde: 'As a Christian Reformed Church we have been led by God's Spirit to adopt this vision: to be A Church Reforming to Reach the Lost for Christ.'

\section{Prediking in 'n missionêre gemeente}

Sedert die publikasie van C.H. Dodd se boek, The apostolic preaching and its developments $(1936)^{10}$ het dit taamlik algemeen

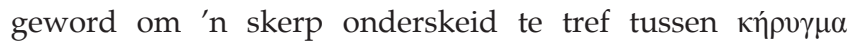

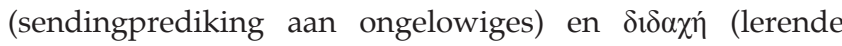
prediking wat veral bedoel is as verdere etiese onderrig aan

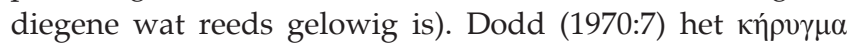
gedefinieer as 'the public proclamation of Christianity to the nonChristian world'. Alan Richardson (aangehaal deur Watson 1978:230) het hierdie onderskeid nog skerper omlyn deur

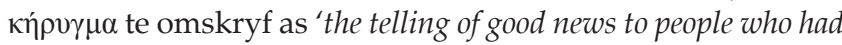
not heard it before'.

Hierdie onderskeiding het die gedagte laat ontstaan dat dit in die kerklike praktyk nodig is om skerp te onderskei tussen opbouende prediking en evangeliserende prediking.

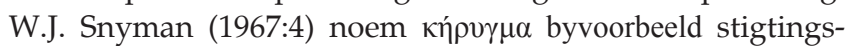
of grondleggende prediking en $\delta i \delta \alpha \sigma \kappa \alpha \lambda i \alpha$ stigtelike of opbouende prediking. Die volgende standpunt kom taamlik algemeen voor: Prediking in 'n gevestigde gemeente hoef slegs lerend of opbouend van aard te wees, maar evangeliserende prediking hoort alleen tuis op die sendingveld of moet slegs tydens spesifieke evangelisasieveldtogte in gemeentes plaasvind. Adams (1982) se standpunt is hiervan 'n goeie voorbeeld:

Earlier I noted that preaching is of two sorts: evangelistic and edificational. Evangelism in the Scriptures is done 'out there', where the unbelieving are, not primarily in the services of the church. (bl. 70)

In gereformeerde kringe is dikwels in die Homiletiek geleer

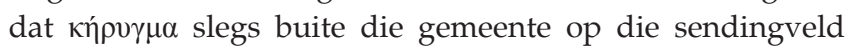
tuishoort. 'n Duidelike eksponent hiervan is Dijk (1955) wat in sy homiletiek die volgende beweer:

Immers draagt vanaf het optreden der apostelen de prediking, welke vanwege de kerk geschiedt, een tweevoudig karakter; zij is een kerugma tot degenen, die buiten zijn, dus naar de wereld gekeerd, welk kerugma in de zending en de evangelizatie zijn arbeidsveld vindt, èn een bediening van het Woord Gods, naar binnen, in de gemeente van Jezus Christus, die als kudde van de goede Herder door dit Woord gewijd wordt. (bl. 95)

10.Vir die doeleindes van hierdie artikel is die 4 e druk (1970) egter gebruik. 
Die standpunte van Dodd en die praktiese implikasies wat daaruit afgelei is, kan egter nie standhou nie, soos R.H. Mounce (1960:60-80) duidelik in sy boek, The essential nature of New Testament preaching, aantoon. Firet (1968:66) toon ook aan dat die standpunt, naamlik dat $\kappa \eta ́ \rho v \mu \alpha$ uitsluitlik tot die missionêre taak van die kerk behoort, wel by Kuyper en Sillevis Smit voorgekom het, maar dat Bakker, Wingren, Van Ruler en Miskotte met oortuigende argumentasie aangetoon

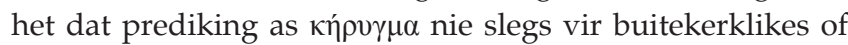
ongelowiges bedoel was nie. Dijk gee ook geen duidelike Skrifberoep vir sy standpunte in hierdie verband nie. Die vraag kan inderdaad gevra word of hierdie skerp onderskeid tussen evangeliserende en lerende of opbouende prediking wel 'n Nuwe-Testamentiese basis het.

Die implikasie van hierdie standpunte is ook dat daar nie ongelowiges en onbekeerdes in die erediens van die gemeente teenwoordig is nie. Die Nuwe Testament hou egter duidelik daarmee rekening dat daar selfs tussen die gelowiges ook skyngelowiges of skynheiliges teenwoordig is (1 Kor 10:6-12; Heb 3:12-13; 4:1; 10:26-29; 1 Joh 2:19; Hand 20:30) en dat nie almal uit Israel werklik Israel is nie (Rom 9:6).

Verder is dit vanselfsprekend dat daar in die eredienste ook ongelowiges mag binnestap (behoort binne te stap; 1 Kor 14:25) en dat 'n gemeente met 'n missionêre hart wat warm klop, moeite sal doen om buitestanders ook na eredienste toe uit te nooi. Hart (1986:72) stel dit dat mense wat in die openbare erediens onder die prediking saamkom 'altyd 'n mengsel van geestelik volwasse mense, onvolwassenes en onbekeerdes' is.

Wanneer alle gegewens nagegaan word, is dit duidelik dat die verkondiging van die evangelie, met gepaardgaande aandrang tot aanvaarding en 'n oproep tot bekering, nie slegs aan ongelowiges op die sendingveld gerig word nie, maar ook in die prediking in die gemeentelike samekomste, met die oog op geloofsverdieping en versterking. Indien daar in die gewone prediking van die gemeente 'n balans is tussen gerigtheid op die kwalitatiewe opbou en groei van die gemeente, sowel as kwantitatiewe opbou en groei, sal die gelowiges bewaar word van hoogmoed en Fariseïsme en van oppervlakkigheid wat by melkkos bly staan het.

\section{Onderrig en toerusting in die gemeente met die oog op intensiewe sowel as ekstensiewe groei}

Volgens die Nuwe Testament is onderrig in 'n sekere sin

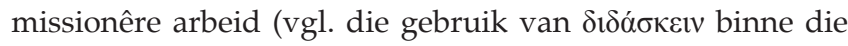
konteks van Hand 5:28; 20:20-21). Van Swigchem (1955:156)

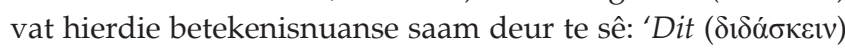
kan een soort missionaire arbeid omvatten'.

In ' $\mathrm{n}$ ander $\sin$ is dit toerusting van gelowiges vir ' $\mathrm{n}$ totale lewe van gehoorsaamheid aan die Here waaronder ook betrokkenheid by missionêre arbeid (vgl. die struktuur van die opdrag in Matt 28:19 waar die dissipels juis geleer moet word om ook van ander dissipels te maak). De Ridder (1971:193) verwoord dit treffend: 'In being obedient to what He has commanded them, they become the agents to pass on that will and commandment to still others.'

Nuwe-Testamentiese onderrig in die gemeente het baie duidelik die karakter van onderrig deur voorbeeld. Dit kan alleen in die konteks van intieme gemeenskapsbeoefening van gelowiges met mekaar geskied waar hulle uit mekaar se lewenswyse en optrede in 'n verskeidenheid situasies kan leer hoe om as kinders van God in die wêreld getuigend tot sy eer te kan leef.

\section{Pastoraat wat toerus vir missionêre arbeid en ook die vrug van kwantitatiewe groei bestendig}

Volgens die Nuwe Testament moet die pastoraat in die gemeente voortdurend 'n missionêre fokus behou. Die pastorale aanwysings in 1 Petrus 3:1-6, 1 Korintiërs 7:1217 en Titus 2:3-5 hou duidelik rekening met missionêre motiewe.

Gelowiges moet in elke aspek van hulle lewe in gedagte hou dat die oë van die buitestanders op hulle gerig is. Hulle moet dus sodanig lewe dat hulle met hulle totale lewenswandel die Woordgetuienis wat hulle bring nie ontkrag nie, maar deur hulle dade en lewenswyse versterk. In pastorale versorging gaan dit nie maar bloot daarom dat mense in hulle nood op 'n empaties-bewoë manier begelei word met die troos van die evangelie nie, maar dat hulle in die pastoraat ook bekwaam gemaak moet word om in die wêreld missionêr-effektief te kan wees. Bolkestein (1964) het dus gelyk wanneer hy die volgende beweer:

Dat zielzorg geen introvert karakter draagt, maar mee opgenomen is in de dienst van de gemeente in de wereld spreekt vanzelf. De 'toerusting' van de gemeente, die in zielzorg word beoogd, betreft mede deze dienst. (bl. 122)

Bolkestein maak hierdie stelling nadat hy die pastoraat volgens Nuwe-Testamentiese riglyne indringend ondersoek het.

Goheen (2011:221) skryf 'n hoofstuk oor hoe die kerk, wat werklik'n lig vir die nasies wil wees, funksioneer. Hy lê groot klem op die wyse waarop huisgesinne en huisgodsdiens uiters belangrike instrumente behoort te wees om by gesinne en veral by kinders 'n missionêre visie aan te kweek.

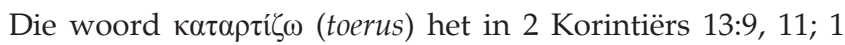
Petrus 5:10 en 1 Tessalonisense 3:10 die betekenisnuanse van om aan te vul wat nog ontbreek. Die implikasie daarvan is dat die pastoraat aan nuwe gelowiges dringend noodsaaklik is om hulle naamlik te bestendig in die nuwe lewe in Christus waarby hulle langs die weg van geloof en bekering ingelyf is.

Uit 1 Korintiërs 5:9-13, gelees binne die konteks van 1 Korintiërs 4 (veral v. 7) blyk dit duidelik dat die gelowiges nooit met ' $n$ hooghartige houding met buitestanders behoort om te gaan nie. Hulle moet altyd met 'n bewoë pastorale grondhouding in missionêre arbeid na buitestanders uitreik. Om dit te kan doen, moet hulle self eers baie diep deur die genade van God getref word. Paulus se vermaning (1 Kor 4:7) moet 'n belydenis en leefwyse word: 'Wat het ons 
wat ons nie ontvang het nie? As julle dit alles ontvang het, wat roem julle dan asof julle dit nie ontvang het nie.'

Met so 'n gesindheid sal die gelowiges se missionêre arbeid inderdaad die karakter dra van 'one beggar telling another where to find bread' soos D.T. Niles dit gestel het (aangehaal in Peters 1975:581). Sodoende kan die gemeente werklik 'die reddingsdade verkondig van Hom wat hulle uit die duisternis geroep het tot sy wonderbare lig' (1 Pet 2:9-10) en word hulle soos Paulus 'deur die liefde van Christus gedring' (2 Kor 5:14) om ander te probeer oortuig. Hulle ervaar dan self die liefde van Christus as 'een even dwingende als heerlijke macht, die hem zozeer beheerst en vervult, dat hij zijn leven wel ten dienste van andere moet stellen' (Van Swigchem 1955:223).

\section{Die kwalitatiewe opbou en evangeliserende impak van die erediens}

Volgens 1 Korintiërs 14:21-25 is dit duidelik dat die samekoms van die gemeente nie net gedien het tot die kwalitatiewe opbou van gelowiges nie, maar ook tot die kwantitatiewe opbou van die gemeente - deur ongelowiges wat deur die aanbiddende en lofprysende gemeente getrek word om tot bekering te kom en deel van die gemeente te word. Dit is ook

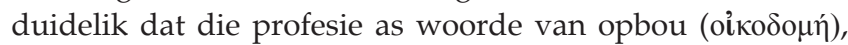
vermaning en bemoediging na die totale liturgiese uiting van die gemeente in die erediens verwys. Dit kan selfs die viering van die Nagmaal insluit, want dit verkondig ( $\kappa \alpha \tau \alpha \gamma \gamma \varepsilon \lambda \lambda \varepsilon \tau \varepsilon)$ ook die dood van die Here totdat Hy kom. Bieder (1964:12) meen daarom dat die kerk in sy erediens en aanbidding en in sy totale lewenswyse iets van 'n sakrament vir die wêreld moet wees. Soos wat die sakramente vir die gelowiges 'Schauplatz der Götlichen Treue' is, so moet die kerk dit ook vir die wêreld wees.

Von Allmen (1965) sê in hierdie verband van die erediens:

By the mere fact of its celebration and because it is a power radiating joy, peace, freedom, order and love, it becomes an evangelizing force, and hence something which impinges upon the surrounding world. Worship provides a sign which is for the world a challenge and promise. Thus it has a power of evangelization hardly guessed at. That is why it is so important that the Christian cult should be celebrated with a maximum of theological urgency and spiritual fervor. (bl. 79)

Die feit dat die erediens ' $n$ evangeliserende impak behoort te hê, beteken nie dat die aanbiddingsdoel in die eerste plek op die bekering van ongelowiges gerig is nie. Ware aanbidding is in die eerste plek op God self gerig. Juis waar Hy in sy heerlikheid en majesteit opreg geloof, geprys en aanbid word, het dit tegelyk ' $n$ invloed op ongelowiges wat teenwoordig is. Die integriteit van die erediens mag nie vernietig word deur daarvan 'n blote evangelisasieveldtog te maak nie.

Die eenheid tussen die kwalitatiewe en kwantitatiewe opbou van die gemeente lê in die Christosentriese, teosentriese karakter van die erediens. Terwyl die teenwoordigheid van Christus deur sy Gees in die woordverkondiging en sakramente, belydenis, gebed en sang gevier word, word sy versoeningsdood terselfdertyd verkondig:
We declare in evangelism that one day everything will stand under his feet (Ephesians 1:22; 1 Corinthians 15:25-28; Hebrews $2: 7-8$ ), and we fall at these same feet in worship (1 Corinthians 14:24-25). The vision of Jesus lifted up is the same in both. (Christian Reformed Home Missions 1984:11.)

\section{Diakonia en koinonia wat kwalitatief en kwantitatief opbou}

Volgens die Nuwe Testament kan kwantitatiewe en kwalitatiewe opbou en groei alleen plaasvind waar daar in die gemeente ' $n$ hegte liefdesgemeenskap tussen gelowiges

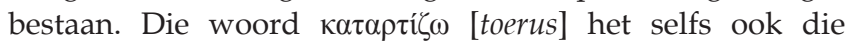
betekenisnuanse van saamsnoer tot 'n eenheid.

Die gelowiges se eenheid met Christus lê 'n dure plig op hulle om ook in eenheid en liefdesgemeenskap met mekaar te lewe (1 Kor 1:10-17; Ef 4:1-7). Omdat gelowiges hulleself aan Christus oorgegee het en in God se lig wandel, het hulle gemeenskap met mekaar (1 Joh 1:7) en gee hulle hulleself ook onvoorwaardelik aan mekaar juis met die oog op die verdere uitdra van die evangelie (2 Kor 8:4-5): 'To embrace the gospel then is to enter into community' (Banks 1980:33). Juis met die doel om effektiewe missionêre instrumente van God te kan wees, moet gelowiges mekaar met selfverloënende liefde liefhê (Joh 13:34-35; 17:21, 23; Fil 1:27), want so word God verheerlik!

Die eerste gemeente in Jerusalem se onderlinge liefde, eenheid en gemeenskap het juis missionêre trekkrag op die buitestanders gehad en ' $n$ belangrike bydrae gelewer tot die getallegroei van die kerk (Hand 2:46-47; 5:13-14; 6:1, 7). Hierdie liefdesdiens mag volgens Jesus se uitdruklike bevel egter nie net op medegelowiges gerig wees nie, want een van die kenmerke van egte Christelike liefdesdiens is dat dit soos Christus se eie liefde onvoorwaardelik is. Dit moet ook betoon word aan diegene van wie nie wederliefde ontvang word nie (Matt 5:46-47; Luk 6:32-33). Deur konkrete dade van liefdesdiens is die gelowiges met daadverkondiging van die evangelie besig (Matt 5:16; 1 Pet 2:12). Waar die kerk dienend in die wêreld teenwoordig is, word die koms van die koninkryk sigbaar.

\section{Strukture waarbinne koinonia en diakonia kwalitatief en kwantitatief opbou}

Die Nuwe Testament gee min voorskrifte oor organisatoriese strukture waarbinne koinonia en diakonia moet plaasvind. Organisatoriese strukture is wel in die Vroeë Kerk deur sekere riglyne bepaal, maar die praktiese vormgewing daarvan is meer pragmaties as prinsipieel bepaal. Gelowiges is beveel om mekaar lief te hê, om met mekaar gemeenskap te beoefen en mekaar te ondersteun in hulle getuienistaak in die wêreld, en dit alles te doen onder die leiding van en toerusting deur die voorgangers. Die konkrete vormgewing van strukture waarbinne dit geskied het, is aan hulle oorgelaat om in die lig van praktiese omstandighede en onder die leiding van die Heilige Gees uit te werk. Eckert (1979) formuleer dit treffend:

The mentality of the earliest Christians did not spring from their desire to found a new religion which would make its presence 
felt in this world for a long time as an institution endowed with a growing bureaucracy and building a lot of churches. They rather saw themselves as an eschatalogical movement which expected final salvation to come, not from the traditional Jewish faith nor from the secular reforms in this world, but from the Christ who would come again in power and glory (see 1 Thess 1:9f; 1 Cor 7:29-31, 16:22; Mrk 13). (bl. 26-27)

Daar bestaan oorvloedige getuienis dat die hegte gemeenskapsbelewing veral in klein huisgemeentes gedy het. Vogler (1982:786-794) beweer - met deeglike bewysvoering - oor die eerste gemeentes in Judea en Galilea: '... dürfte unbestritten sein, dass diese Gemeinden Hausgemeinden waren. Denn zu dieser Zeit gab es noch keine kirchlichen Räume oder Gebäude'. Dit is inderdaad so dat daar nie getuienis bestaan van enige kerkgeboue voor die derde eeu na Christus nie (Banks 1980:41).

Die huisgemeentes (Rom 16:5; 1 Kor 16:19; Kol 4:15; Fil 2) het ruimte gebied vir intieme gemeenskapsbelewing, maar het ook 'eine intensive Ausbreitung des Evangeliums betrieben und diese Ausbreitung hat sich nicht nur auf Jüden, sondern auch auf Heiden erstreckt' (Vogler 1982:787). Hierdie bevindings is opnuut deur Hirsch (2006:198) bevestig wat van mening is dat ' $n$ wegbeweeg van die institusionele kerkbegrip na meer vloeibare strukture die Nuwe-Testamentiese styl van kerkwees reflekteer (vgl. ook Stezer 2006:170 e.v. wat die term koinos-kerke gebruik). Goheen (2011:223) beklemtoon dat 'n missionêre kerk 'n kerk is met kleingroepe wat 'n missionêre bewustheid kweek.

Die vertelling oor die eerste Christelike gemeente in Jerusalem is merkwaardig. Hulle het in die tempel en in die Pilaargang van Salomo vergader (Hand 3:11; 5:12), maar

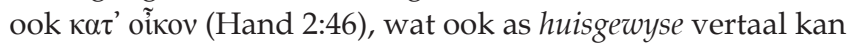
word. In die samekomste het gebed klaarblyklik 'n vername plek beklee (Hand 12:12), maar ook die leer van die apostels, die onderlinge gemeenskap en die gesamentlike maaltye (Hand 2:42-47). Hoe strukture ook al ingeklee word, moet dit so gedoen word dat sowel die impak van die groot samekoms in die erediens as die intieme meelewing van kleingroepbediening gestimuleer word.

\section{Die funksionering van charismata}

Volgens die Nuwe Testament is dit duidelik dat elke gelowige gawes ontvang het wat in die bediening tot opbou van die gemeente gebruik moet word. Dit is merkwaardig hoe dikwels die woorde almal en elkeen in al die teksgedeeltes voorkom wat oor die gawes van die Heilige Gees handel (Rom 12:3; 1 Kor 12:11 en 28-31; Ef 4:7 en 1 Pet 4:10). Waar elke gelowige sy of haar gawes gebruik, word die gemeente kwalitatief sowel as kwantitatief opgebou.

Die feit dat alle gelowiges gawes het beteken egter nie dat daar nie ook bepaalde gelowiges is wat met hulle gawes as voorgangers moet funksioneer nie. Die voorgangers se taak is egter tweërlei van aard. Hulle moet die dienswerk van al die gelowiges koördineer en gelowiges ook toerus vir hulle dienswerk (Ef. 4:7-16 en Kol 2:20; vgl. ook Buys 1989:109,
245 e.v.; Roberts 1983:124; Versteeg 1985:27). Die toerusting deur voorgangers moet deur woorde maar ook met hulle voorbeeld gedoen word (1 Pet 5:3; 1 Kor 4:16; 11:1; Fil 3:17; vgl. ook Zemek 1993:170-185).

Die implikasie is dat die voorgangers en die ander gelowiges in die gemeente dieselfde basiese funksies vervul in die opbou van die gemeente. Voorgangers se arbeid is slegs 'n toespitsing van die taak wat alle gelowiges doen (Roberts 1983:15). Voorgangers wat nie daarin slaag om gelowiges onder hulle sorg te motiveer en tot dienswerk te begelei volgens hulle eie gawes nie, vervul nie werklik hulle roeping nie.

\section{'n Missionêre kerk is 'n biddende kerk}

Die primêre instrument wat die Heilige Gees gebruik om kwalitatiewe sowel as kwantitatiewe groei in die gemeente van Christus te bring, is die bediening van die evangelie van Jesus Christus (1 Pet 1:23; Rom 10:17; Heidelbergse Kategismus [HK] vr. 65). God die Heilige Gees is egter soewerein en skenk nie outomaties oral en altyd waar die evangelie bedien word, groei nie. Dit is die sogenaamde per verbo-standpunt van die Lutherane, wat beteken dat die Heilige Gees outomaties werk waar die Woord verkondig word. Die cum verbo-standpunt van Calviniste bely dat die Heilige Gees saam met, dit wil sê in, onder en deur die bediening van die evangelie in mense se harte werk slegs wanneer dit Hom behaag.

Die Heilige Gees laat Hom egter deur die gebede van God se kinders beweeg. Dit is 'n onverstaanbare en onnaspeurlike geheim. In die proses waarmee Hy die getalle van die uitverkorenes laat vol word en hulle aan die beeld van Christus gelyk maak, skakel die ewige God ons gebede in. God gee egter 'sy genade en sy Heilige Gees slegs aan diegene wat Hom met hartlike sugte sonder ophou daarom bid en daarvoor dank' (HK So 45). Dit was Jesus Christus se bedoeling dat gebed 'n groot krag moes wees waardeur die kerk medewerkers in die koms van die koninkryk is.

Met betrekking tot groei, stel die Bybel die eis dat daar onder andere voortdurend gebid word, naamlik:

- dat God die nodige gewillige medewerkers vir georganiseerde en gestruktureerde evangeliseringswerk sal gee (Matt 9:38);

- dat die mense wat die evangelie hoor se harte deur die Heilige Gees oopgemaak sal word (Kol 4:2);

- dat die Heilige Gees aan diegene wat die praatwerk doen die nodige vrymoedigheid, insig en oortuigingskrag sal gee (Hand 4:29; Ef 6:19);

- vir nuwe gelowiges se geloofsgroei en hulle bewaring teen die aanvalle van die duiwel (Fil 1:9-10);

- vir enige spesifieke behoeftes in die werk van die Here wat tot sy eer is en sy naam wil verheerlik (Fil 4:6);

- om medewerkers te wees in die verkondiging van die evangelie (Rom 15:30).

Michael Green (1992) het indringend navorsing gedoen oor die geheim van groei in die Vroeë Kerk in die eerste drie eeue 
na Christus en het verskeie publikasies daaroor die lig laat sien, wat uitgebreid in sy Comprehensive guide to all aspects of evangelism saamgevat is. Green se formulering van die belang van gebed as prioriteit in missionêre gemeenteopbou is treffend:

Do you know a church where the priority is prayer? Prayer in individual lives, in prayer cells, in half-nights of prayer? If you do, I can tell you one thing about that church. It will be evangelizing. In some way or other the good news of Jesus will be going out. Prayer is a priority in evangelism. Without it lives do not get changed however great the activism and however enthusiastic the proclamation. Most churches do not see church growth because they do not want it enough to pray for it. (Green 1979:27)

\section{Slot}

Slegs 'n groeiende deurleefde visie op die drieënige God in sy majestueuse heerlikheid en heiligheid en oorbluffende genade vir sondaars maak van 'n kerk hoe langer hoe meer 'n kerk met 'n visie en 'n passie om met woorde en dade deel te word van God se sending. So 'n kerk sal in al die aspekte van die funksionering van die gemeente, naamlik in prediking, onderrig, die pastoraat, aanbidding in die gesamentlike erediens en die opsig, bestuur en leiding van die voorgangers, 'n integrale eenheid handhaaf tussen die kwalitatiewe en kwantitatiewe opbou, groei en die bewaring en vermeerdering van die kerk. Om te kan bewaar, moet die kerk voortdurend op vermeerdering gerig wees. Om te kan vermeerder, moet die kerk in 'n hegte liefdesverhouding met God en met mekaar bewaar word.

Slegs waar die gemeente voluit as liggaam van Christus leef en werklik deur sy liefde gedring word om in 'n gebroke wêreld kanale van sy liefde - deel van God se strome van lewende water - teenoor alle mense te wees, sal die kerk effektief in getalle sowel as in geestelike diepte en godsvrug groei.

\section{Erkenning Mededingende belange}

Die outeur verklaar dat hy geen finansiële of persoonlike verbintenis het met enige party wat hom nadelig kon beïnloed het in die skryf van hierdie artikel nie.

\section{Literatuurverwysings}

Allen, R., 1983, Missionary methods: St. Paul's or ours, Eerdmans, Grand Rapids. Adams, J.E., 1982, Preaching with purpose, Baker, Grand Rapids.

Atoyebi, P., 2010, 'From stagnation to revitalization: A study of select turnaround churches in the urban context of Nairobi, Kenya', PhD dissertation, Faculty of Theology, North-West University.

Banks, R., 1980, Paul's idea of community: The early house churches in their historical setting, Paternoster, Exeter.

Bieder, W., 1964, Das Mysterium Christi und die Mission: Ein Beitrag zur Missionarischen Sakramentsgestalt der Kirche, EVZ Verlag, Zurich.

Bolkestein, H.M., 1964, Zielzorg in het Nieuwe Testament, Van Keulen, Den Haag.

Bosch, D., 1991, Transforming mission: Paradigm shifts in theology of mission, Orbis Books, New York.

Botha, N., 2005, 'Dink ook aan die ander se belange ...', Die Kerkblad, November, 9.

Buys, P.J., 1984, 'Die aard van die verbond en die implikasies daarvan vir evangelisasie', ThM verhandeling, Fakulteit Teologie, PU vir CHO.
Buys, P.J., 1989, 'Die verhouding tussen gemeenteopbou en evangelisering: ' $n$ Eksegetiese ondersoek na die betekenis van tersaaklike woorde in die Nuwe Testament en die implikasies daarvan vir die verhouding tussen die bewaring en die vermeerdering van die kerk', ThD proefskrif, Fakulteit Teologie, PU vir CHO.

Buys, P.J., 1999, 'Manila topic '99 report: Back to the drawing board with theological education to reach at least two million untrained pastors in economically weaker areas of the world', viewed 15 August 2009, from www.topic.us/

Breedt, J.J., 2009, 'Kerk 24/7 -'n Gevallestudie van 'n ontluikende geloofsgemeenskap in George', MTh verhandeling, Fakulteit Teologie, Universiteit van Stellenbosch.

Carson, D.A., 2005, Becoming conversant with the Emerging Church: Understanding a movement and its implications, Zondervan, Grand Rapids.

Carter, C.A., 2006, Rethinking Christ and culture: A post-Christendom perspective, Brazos, Grand Rapids.

Christian Reformed Churches of Australia, 2006, 'Ministry formation Christian reformed churches of Australia: A church reforming to reach the lost for Christ', viewed 14 August 2009, from http://www.ministryformation.crca.org.au/index php?option=com_content\&view=article\&id=55\&ltemid $=41$

Christian Reformed Home Missions, 1984, Evangelism and worship, Christian Reformed Home Missions, Grand Rapids.

Clowney, E.P., 1958, 'Secularism and the Christian Mission', Westminster Theological Journal 21(1), 18.

Dayton, R. \& Engstrom, W., 1989, Strategy for leadership: God's principles for churches and Christian organisations, Mandaluyong Manila, OMF Literature. PMCid:286800

De Klerk, B.J., 2007, 'Op pad na 2019 ... die GKSA en die 150-jarige fees, Die Kerkblad, November, 9.

De Ridder, R.R., 1971, The dispersion of the people of God: The covenant basis of Matthew 28:18-20 against the background of Jewish, pre-Christian proselyting and diaspora, and the apostleship of Jesus Christ, Kok, Kampen.

De Young, K. \& Gilbert, G., 2011, What is the mission of the church? Making sense of social justice, shalom and the great commission, Crossway, Wheaton.

Dijk, K., 1955, De dienst der prediking, Kok, Kampen.

Dodd, C.H., 1970, The apostolic preaching and its developments, 4th edn., Hodder \& Stoughton, London.

Driscoll, M., 2007, 'The church and supremacy of Christ in a postmodern world', in J. Piper \& J. Taylor, The supremacy of Christ in a postmodern world, p. 88, Crossway Books, Wheaton.

Eckert, J., 1979, 'The realisation of fellowship in the earliest Christian communities' in J. Pohier \& D. Mieth (eds.), The dignity of the despised of the earth, pp. 26-27, Seabury Press, New York.

Escobar, S., 2003, The new global mission: The gospel from everywhere to everywhere, InterVarsity, Downers Grove.

Firet, J., 1968, Het agogisch moment in het pastoraal optreden, Kok, Kampen.

Gaum, F., 2012, Fluit-fluit die kerk is uit? Rigtingwysers vir die oorlewing en geloofwaardigheid van die kerk, Bybel-Media, Wellington. PMid:22194430

Gereformeerde Kerke in Suid-Afrika, 1985, Handelinge van die twee-en-veertigste nasionale sinode, Administratiewe Buro, Potchefstroom.

Gereformeerde Kerke in Suid-Afrika, 2012, Handelinge van die tweede algemene sinode, Administratiewe Buro, Potchefstroom.

Glenn, R.W., 2007, 'Towards a biblical vision of missions', viewed 05 April 2012, from http://solidfoodmedia.com/resources/series/toward_a_biblical_view_of missions/

Goheen, M.W., 2000, '“As the Father has sent Me, I am sending you": J.E. Lesslie Newbigin's missionary ecclesiology; "Zoals de Vader mij gezonden heeft, zend Ik u": J.E. Lesslie Newbigin's missionaire ecclesiologie', ThD dissertation, Faculty of Theology, University of Utrecht.

Goheen, M.W., 2011, A light to the nations: The missional church and the biblical story, Baker Academic, Grand Rapids.

Guder, D.L. (ed.), 1998, Missional church: A vision for the sending of the church in North America, Eerdmans, Grand Rapids.

Green, M., 1979, Evangelism - Now and then, Intervarsity, Leicester.

Hart, D.J., 1986, 'Prediking en evangelisasie', in B.J. van der Walt (red.), Sodat My huis vol kan word: Reformatoriese perspektiewe op ons evangelisasieroeping vandag, p. 55, PU vir $\mathrm{CHO}$, Potchefstroom.

Hirsch, A., 2006, The forgotten ways: Reactivating the missional church, Brazos Press, Grand Rapids.

Jenkins, P., 2002, The next Christendom: The rise of global Christianity, Oxford University Press, Oxford. http://dx.doi.org/10.1093/0195146166.001.0001

Jenkins, P., 2006, The new faces of Christianity: Believing the Bible in the global South, Oxford University Press, Oxford.

Jenkins, P., 2009, God's continent: Christianity, Islam, and Europe's religious crisis, Oxford University Press, Oxford.

Jones, T., 2003, Soul shaper: Exploring spirituality and contemplative practices in youth ministry, Zondervan, Grand Rapids.

Jones, T., 2005, The sacred way: Spiritual practices for everyday life, Zondervan, Grand Rapids.

Jordaan, G.J.C., Van Rensburg, F.J. \& Breed, D.G., 2011, 'Hermeneutiese vertrekpunte vir gereformeerde eksegese', In die Skriflig/In Luce Verbi 45(2\&3), 225-258.

Keifert, P., 2006, We are here now: A new missional era, Allelon, Eagle-Idaho. 
Keller, T., 2001, 'The missional church', viewed 02 April 2012, from http://www. redeemer2.com/resources/papers/missional.pdf

Kruger, G., 2006, 'Die redakteur gesels met Ds. Gerrit Kruger', Die Kerkblad, Desember, 9.

Landrey, J.P., 2009, 'Trainers of pastors international coalition', viewed 15 August 2009, from www.topic.us

McLaren, B.D., 2000, The church on the other side: Doing ministry in the postmodern matrix, Zondervan, Grand Rapids.

McLaren, B.D., 2001, A new kind of Christian: A tale of two friends on a spiritual journey, Jossey Bass, San Francisco.

McLaren, B.D. 2003. The story we find ourselves in: Further adventures of a new kind of Christian, Jossey-Bass, San Francisco.

Miller, C.J., 1986, Outgrowing the ingrown church, Zondervan, Grand Rapids.

Monrovia, S.R., 2000, 'The Lord's business', TIME World, 07 February 2000, viewed 12 April 2012, from http://www.time.com/time/world/article/0,8599,2050231,00. htm

Mounce, R.H., 1960, The essential nature of New Testament preaching, Eerdmans, Grand Rapids.

Newbigin, L., 1989, The gospel in a pluralist society, Eerdmans, Grand Rapids.

Ogden, G., 1990, The New Reformation; Returning the ministry to the people of God, Zondervan, Grand Rapids.

Onvoltooide sendingtaak, http://www.uscwm.org/uploads/pdf/psp/winter_koch_ finishingthetask.pdf

Peters, G.W., 1975, 'Contemporary practices of evangelism', in J.D. Douglas (ed.), Let the earth hear his Voice, pp. 571-583, World Wide Publications, Minneapolis.

Paas, S., 2006, 'Kerken vormen: De gemeenschappelijke structuur van het Evangelie anno nu', Soteria 23(1), 6-26.

Piper, J., 1993, Let the nations be glad!: The supremacy of God in missions, Baker Books, Grand Rapids. PMCid:1793872

Rennstich, K.W., 1993, Pfarrerfortbildung in einer pluralistischen Gesellschaft am Beispiel des Pastoralkollegs Urach, Vortrag Pfarrkonvent Stuttgart am 9. Juni 1993, Pastoralkolleg, Bad Urach.

Roberts, J.H., 1983, Die brief aan die Efesiërs, NG Kerk-Uitgewers, Kaapstad.
Smit, C.J., 2009,' Laat die sangers vooruit gaan ... die stryd tegemoet!', Die Kerkblad, April, 4.

Snyman, S., 2008, 'Die redakteur gesels met Stefanie Snyman', Die Kerkblad, Augustus, 9.

Snyman, W.J., 1967, Openbaringsgeskiedenis Nuwe Testament: Die vier evangelies, Pro Rege, Potchefstroom. PMid:4174734

Stetzer, E., 2006, Planting missional churches, B\&H Academic, Nashville.

Te Velde, M., 1992, Gemeenteopbouw 2: Bijbelse basisprincipes voor het functioneren van de christelijke gemeente, Vuurbaak, Barneveld.

Van Engen, C.E., 1991, God's missionary people: Rethinking the purpose of the local church, Baker Books, Grand Rapids. PMid:1812913

Van Loggerenberg, M., 2007, 'Die redakteur gesels met Marina van Loggerenberg', Die Kerkblad, Desember, 10.

Van Rensburg, J.J., 2011, Jesus is die een!: Verloor ons nie die evangelie in die Emerging Church nie?, Christelike Media Publikasies, Bloemfontein.

Van Swigchem, D., 1955, Het missionair karakter van de christelijke gemeente volgens de brieven van Paulus en Petrus, Kok, Kampen.

Venter, J., 2011, Oesversekering, Die Kerkblad, Maart, 5.

Versteeg, J.P., 1985, Kijk op de kerk: De struktuur van de gemeente volgens het Nieuwe Testament, Kok, Kampen. PMCid:1415690

Vogler, W., 1982, 'Die Bedeutung der urchristlichen Hausgemeinden für die Ausbreitung des Evangeliums', Theologische Literaturzeitung 107(11), 785-794.

Von Allmen, J.J., 1965, Worship: Its theology and practice, Lutterworth, London.

Watson, D., 1978, I Believe in the church, Hodder \& Stoughton, London.

Woodbridge, N.B., 2008, 'Evaluating the changing face of worship in the Emerging Church in terms of the ECLECTIC model: Revival or a return to ancient traditions?', in Conspectus, vol. 5, p. 30, South African Theological Seminary, Rivonia.

Wright, C., 2006, The mission of God: Unlocking the Bible's grand narrative, InterVarsity, Downers Grove.

Wright, C.H., 2010, The mission of God's people: A biblical theology of the church's mission, Zondervan, Gand Rapids.

Zemek, G.J., 1993, 'The modeling of ministers', Master's Seminary Journal 4(4), $170-185$. 